\title{
NESTING BEHAVIORAL ADAPTATIONS OF ORANGUTAN (PONGO PYGMAEUS MORIO) IN COAL MINING AREA IN EAST KALIMANTAN
}

\author{
Liza niningsih $^{1^{\star}}$, Sri Suci Utami Atmoko ${ }^{2}$, Hadi S. Alikodra ${ }^{3}, \&$ Yeni A. Mulyani ${ }^{3}$ \\ ${ }^{1}$ Department of Forestry, Kutai Timur College of Agricultural, Sangatta, Kutai Timur 75683, \\ Kalimantan Timur, Indonesia. \\ ${ }^{2}$ Faculty of Biology, Nasional University, Pasar Minggu, Jakarta 12520. \\ ${ }^{3}$ Department of Conservation of Forest Resources and Ecosystem, Faculty of Forestry, IPB \\ University, Campus IPB Dramaga, Bogor 16680. \\ *Email : lizaniningsih@stiperkutim.ac.id.
}

Received: 19/01/2021, Revised: 06/07/2021 Accepted: 07/07/2021

\begin{abstract}
Coal mining changed forest structure and composition, it caused large negative impacts on the orangutan. In order to mitigate those negative effects, it is crucial to understand their nesting behavior adaptation in mining area. We investigated 74 times nested event in coal mining rehabilition area (CMRA) in East Kutai and 123 times in the Kutai National Park (Prevab) from October 2013 to September 2014 and include only night nests. We compared both habitats. Orangutans in CMRA built the nest later than in Prevab and used 15 species of trees as nests sites intensively on Senna siamea and Gmelina arborea. In Prevab, 35 species with the higher frequencies on Eusideroxylon zwageri and Dracontomelon dao. The average diameter of nest trees in CMRA smaller than Prevab. The height of nest trees in CMRA with the highest frequency was in 10.1-15 m, while in Prevab was as in 20.1-25 m. Orangutans in CMRA nested at the height of $<15 \mathrm{~m}$, lower than in Prevab was $>20 \mathrm{~m}$. Reused nest in CMRA was higher than in Prevab. Orangutans in CMRA more often built nests at the peak and limb, while in Prevab at the limb and peak. Orangutans in CMRA had learned to utilize various species and dimensions of trees as the place to build nests.
\end{abstract}

Keywords: habitat change, nest trees, night nest.

\section{INTRODUCTION}

The great apes build night nests exclusively on the trees (Tutin \& Fernandez 1984; Hall et al. 1998; Poulsen \& Clark 2004). Theoretically, one of their reasons establishes it is an anti-predators strategy (Anderson 2000). The natural predator of Bornean orangutan that has been reported is Neofelis diardi (MacKinnon 1974; van Schaik 1983). Other motives are to avoid contact with nocturnal frugivores (Anderson 2000), to comfort sleep (Stewart et al. 2007), to better sleep quality (Anderson 1998), and as an anti-vector of diseases (McGrew 2004). The nest structure is important to increase the security of great apes during sleeping (Baldwin et al. 1981).

Orangutans built nests every day and become a reliable indicator of their existence in an area (MacKinnon 1974; Ancrenaz et al. 2004; Morrogh-Bernard et al. 2009). The 
great apes nesting pattern can be affected by differences of season, habitat, age, sex (Fruth \& Hohmann 1994), learning and culture (Humle 2003; Baldwin et al. 1981; McGrew 2004), or combination of some those factors (Brownlow et al. 2001; Koops et al. 2012). It is also influenced by predation (Ogawa et al. 2007), for instance, building higher nests (Pruetz et al. 2008; Stewart \& Pruetz 2013). The study regarding the orangutan nesting behavior is important due it can be relied on to estimate the orangutan population (van Schaik et al. 2005; Sanz et al. 2007) and contribute crucial information about their ecological adaptation (McGrew 2010).

The loss, degradation, and fragmentation of habitats can modify behavioral aspects of animals (Gunawan \& Prasetyo 2003). Animals are bounded to certain locations that are considered comfort and their emotion will be distracted if their habitats changed or forced to move (Wich et al. 2015). Change on food resources can escalate the time of looking for food and decrease time to finding a spouse, in turn, will influence the success of reproduction (Campbell et al. 2008). To be sustained in a disturbing habitat, orangutans must be capable of adaptation.

Behavioral flexibility delivers an important fitness benefit for animals in a new or changing environment (Reader \& MacDonald 2003; Sol 2003; Sol et al. 2002). The capability of animals in adaptation is highly affected by behavior, hence, some species can be survived and even develop in a habitat that undergoes anthropogenic disturbances (Sih et al. 2011; Candolin \&Wong 2012; Sih 2013). Orangutans are sensitive to the annoyance connectivity of forest canopy; however, they have the capability in adaptation. They have capacity to learn, conclude, possess long-term memory, and understand environmental signs (Meijaard et al. 2001). They also can survive in various degraded landscapes signifying their tolerances on habitat disturbance, for instance, living in surrounding oil palm plantation (Ancrenaz et al. 2014; Rayadin \& Spehar 2015), forest plantation (Ngatiman 2001; Rayadin \& Saitoh 2009), agroforest (Campbell-Smith G et al. 2011), logged-over forest (Husson et al. 2009; Hardus et al. 2012), and coal mining areas (Rayadin et al. 2012; KPC 2013; Niningsih 2017). Their adaptation capability limited by food, nesting trees, temperature, humidity, and water. They are going to survive in a certain area as long as their minimum needs are available (Lynch \& Gabriel 1987).

Orangutans have discovered a unique manner to survive in a limited habitat condition, though, their population continues decreasing (van Schaik 2006). The changes in habitat characteristics and quality in coal mining can shove the orangutans to modify their behaviors like nesting behavior. This is the first nesting behavior research of orangutans at CMRA using the direct observation (the focal animal sampling). This information to help researchers understand the orangutans adaptation in optimizing the use of resources at CMRA, especially to build the nests. This research was aimed at analyzing the nesting behavioral adaptation of orangutans (Pongo pygmaeus morio) in the coal mining areas of East Kalimantan. An understanding of this adaptation is crucial to mitigate the negative impacts of mining activities on orangutans.

\section{METHODS}

This research was carried out in two areas consisting of the coal mining rehabilitation area of $P T$ Kaltim Prima Coal/KPC (which is then called as CMRA), and Prevab Natural Habitat of Kutai National Park (then styled as Prevab), East Kutai Regency, East Kalimantan Province. Geographically, Kutai National Park is located at 0'7'54"- $0^{\circ} 33^{\prime} 53^{\prime \prime}$ north latitude and 116 $58^{\prime} 48^{\prime \prime}$ - 117 35'29" east longitude (BTNK 2005) while PT KPC at $0^{\circ} 31^{\prime 20}$ '52"-0 52 '4.6" North Latitude and $117^{\circ} 27^{\prime} 7.4^{\prime \prime} B T-117^{\circ} 40^{\prime} 43.4^{\prime \prime}$ east longitude (KPC 2020). Most of the study area is located at an altitude below 100 meters above sea level. The Schmidt \& Ferguson system classified the climate of the research area as wet climate with the relative humidity around $63 \%$ to $100 \%$. Monthly rainfall recorded at PT KPC's Tanjung Bara weather station from October 2013 to 
September 2014 ranged from $96.5 \mathrm{~mm}$ - $273.1 \mathrm{~mm}$ with the highest monthly precipitation in November 2013. Collecting the field data was taken from October 2013 to September 2014.

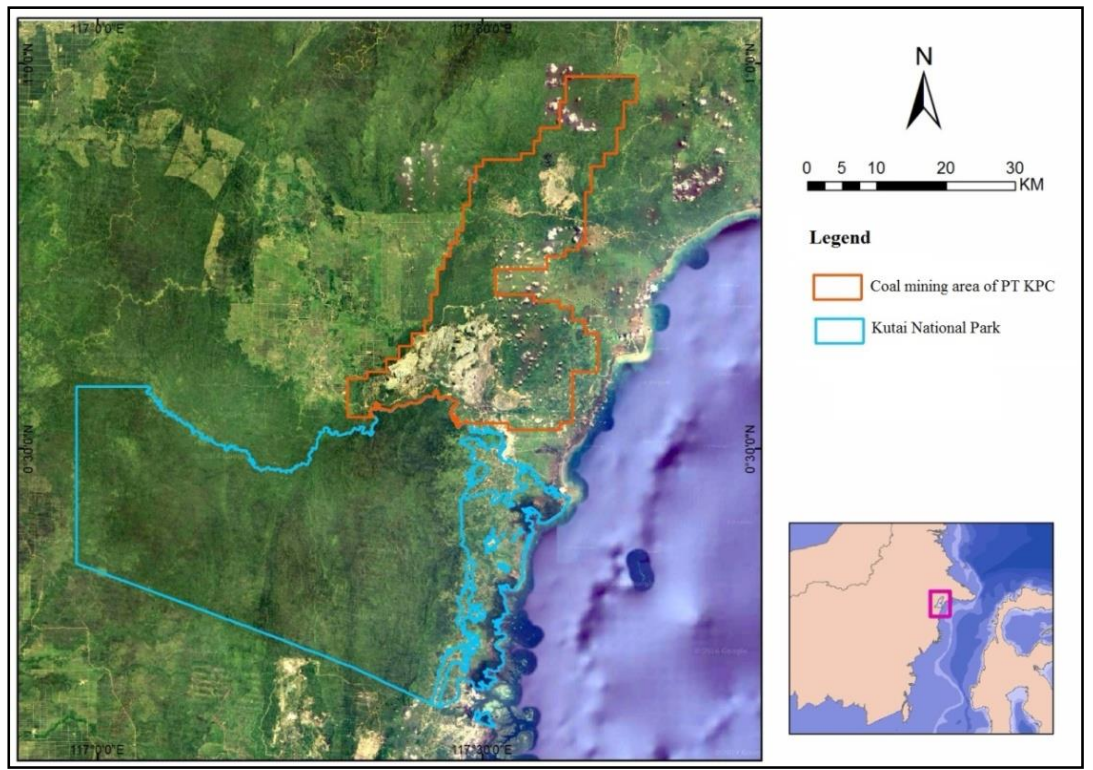

Figure 1. The study area at CMRA and Prevab, East Kutai, East Borneo.

\section{Procedures}

The monitored parameters of orangutans' nesting behavior in this research were: (a) time duration of making nest; (b) characteristics of nest trees consisting of species, tall, and diameter; (c) nest characteristics such as the nest high from ground level, nest protection by tree canopy, nest position on the tree, and nest type.

The nest protection by tree canopy was distinguished becoming a closed nest and opened nest. Further, the nest position on the tree followed a classification of Prasetyo et al. (2009) dividing into four positions of nest namely (1) locating on the axilla and center of branches; (2) edge of branches; (3) top of tree; (4) two or more trees; and (0) on the ground level (Figure 4.1). The built nest of orangutan was classified into two types such (1) new nest: the orangutan built new nest using fresh materials of branches/limbs/leaves/others; (2) reused nest: the orangutan reused the old nets either repairing or without any reparation. Orangutan usually repaired the old nest by adding fresh leaves or limbs. The nest can belong to both the same individualand other individuals.

\section{Data analysis}

A descriptive analysis utilizing average, range, and percentage, was used to explain the starting time and duration of building the nest, species of the nest tree, tree dbh (diameter at breast height) of nest, tree high of the nest, nest high from ground, nest position on the tree, and nest protection by tree canopy. The analysis results then were presented in graphics and tables.

A non-parametric statistic test of Mann-Whitney was applied to observe the nesting behavioral differences among the orangutans living in the CMRA and Prevab (Sugiyono 2007). The species similarity index STrensen (ISS $\left.=\frac{2 c}{A+B} \times 100 \%\right)$ was used to determine the tree species similarity of orangutan nests between both habitats. $A, B$, and $C$ are the 
number of nested tree species in the CMRA, Prevab, and both habitats, respectively (Curtis 1959).

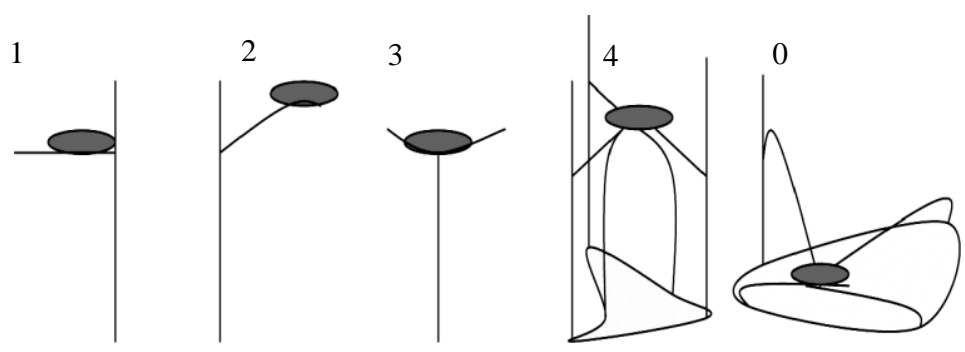

Figure 2. Classification of orangutan nest location on trees (Prasetyoet al. 2009).

\section{RESULTS AND DISCUSSION}

\section{Result}

The orangutans in the CMRA begin building nests in an average of \pm 33 minutes before sunset namely at $5.39 \mathrm{pm}$ at Central Indonesia Time (between $2.54 \mathrm{pm}$ and $7.02 \mathrm{pm}$ ). In Prevab, they started establishing nests in an average of 55 minutes before sunset namely at5.21 pm at Central Indonesia Time (between $5.14 \mathrm{pm}$ and $6.38 \mathrm{pm}$ ).

The orangutans in the CMRA and Prevab need times in an average of 6.7 minutes and 6.5 minutes to finish their night nest structures, respectively. The analysis results of Mann Whitney denote an insignificant difference of orangutans in both habitats (N: 196; P 0.903 > 0.05).

\section{Tree characteristics of nest}

We identified 15 trees species that used by orangutans as nest trees in the CMRA. Johar (Senna siamea) and gmelina (Gmelina arborea) possess a high frequency of uses namely $43.42 \%$ and $26.32 \%$, respectively. Figure 3 presents the female orangutans with her baby built a nest on johar and gmelina. The nest tree species and frequency of use conducting by the orangutans in the CMRA can be seen in Figure 4.
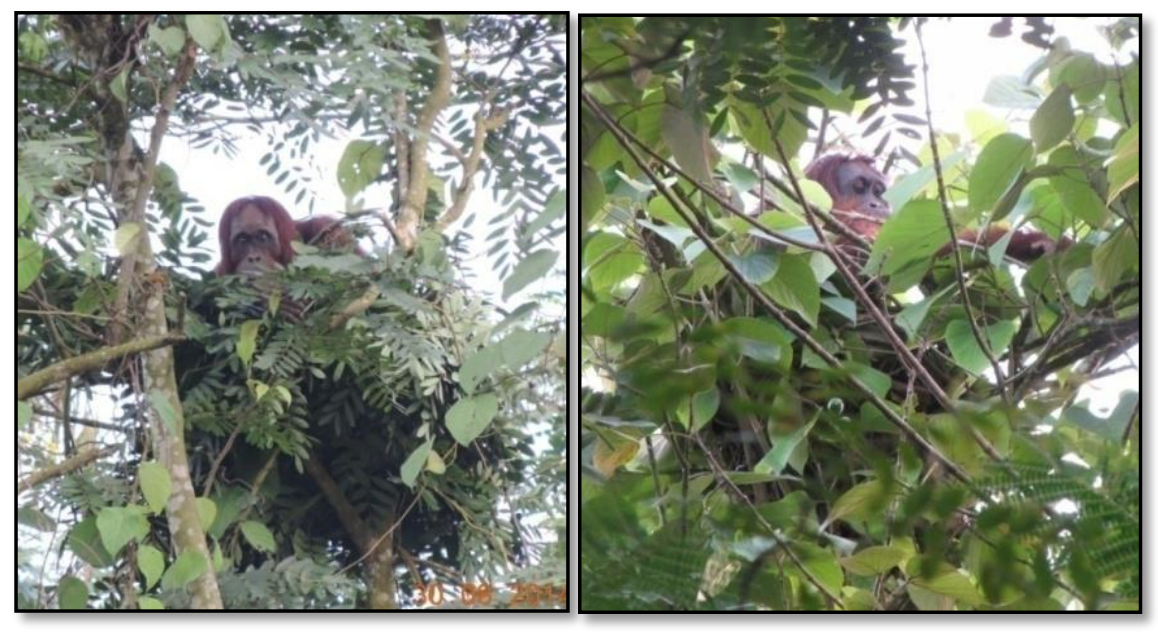

[101] This work is licensed under a Creative Commons Attribution 4.0 International License 
Figure 3.Orangutans in CMRA build their the nest intensively on Senna siamea (left) and Gmelina arborea (right)

In Prevab, about 35 identified tree species are utilized by orangutans as their nesting place and only 7 species of them possessing frequencies of use more than $5 \%$. Tree species like Borneo ironwood or ulin (Eusideroxylon zwageri), sengkuang (Dracontomelon dao), and Bayur (Pterospermum spp.) are frequently utilized by orangutans as their nest trees with frequencies of use consisting of $15.45 \%, 13.01 \%$, and $12.20 \%$, respectively (Figure 5).

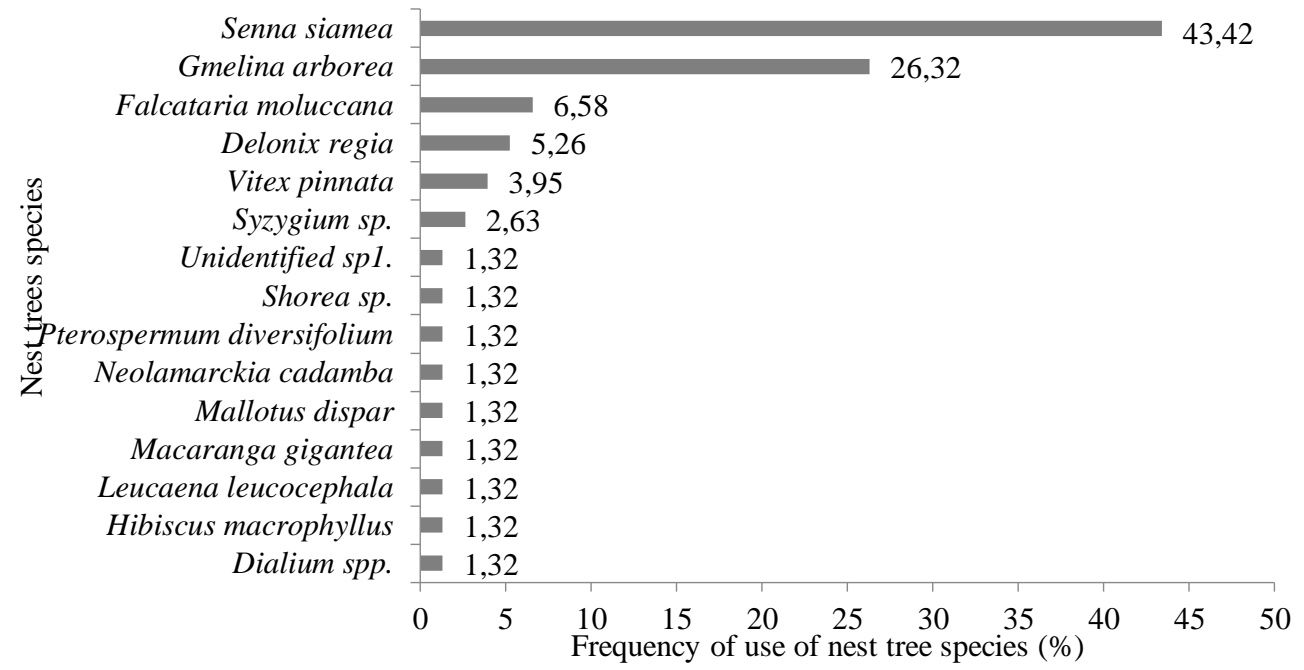

Figure 4. Tree species used for the nest by orangutans and their frequencyof use at CMRA.

About 19 of 35 nest tree species in Prevab that cover the frequencies of use less than 1\%. Those three species are Aglaia odorata, Antiaris toxitoria, Castanopsis sp., Dillenia exelsa, Dryobalanops sp., Ficus sp., Glochidion sp., Knema latericia, Lophopetalum javanicum, Macaranga gigantea, Octomeles sumatrana, Pimeliodendron zoanthogyne, Planchonia valida,Unidentified1, Unidentified2, Unidentified3, Unidentified4, Unidentified5, and Unidentified6.

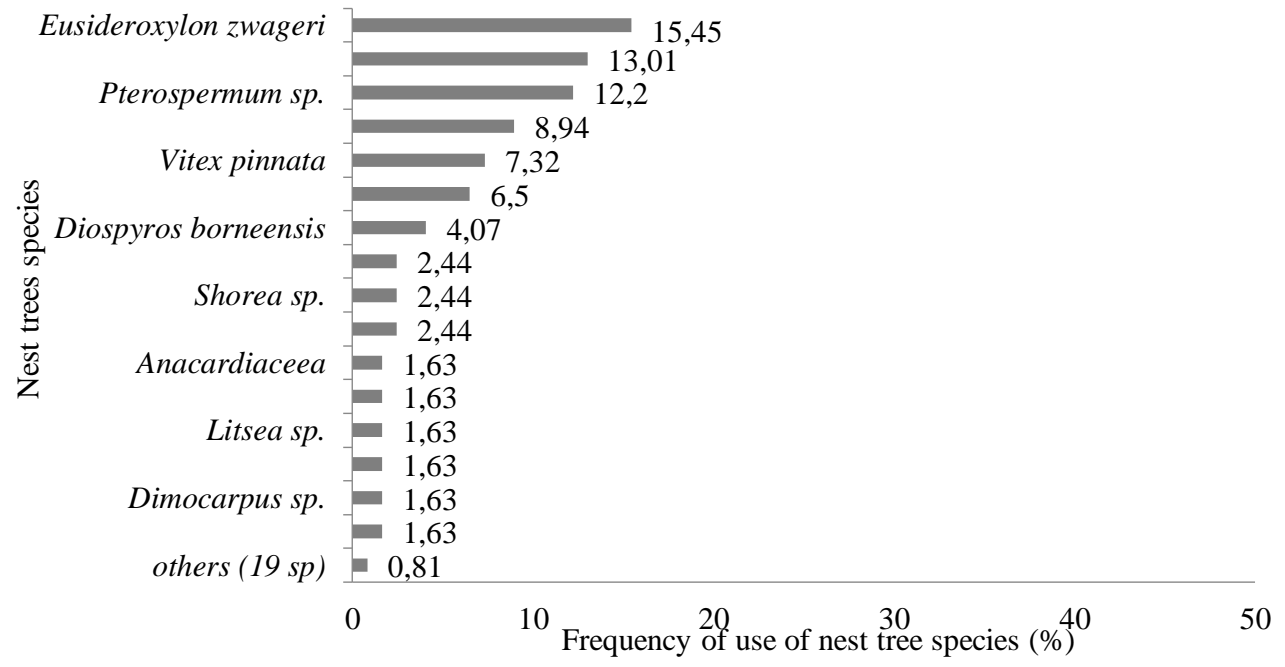

Figure 5.Tree species used for nest by orangutans and their intensity of use at Prevab, Kutai National Park 
The result of calculated the species similarity index (STrensen, ISs) of nest trees between two locations, CMRA and Prevab, was about 16\%. The nest tree species which is applied by orangutans in both locations are only four species namely Macaranga gigantea, Syzygium sp., Pterospermum sp., and Vitex pinnata. Most of the nest trees in the Prevab were not found in the CMRA and reversely.

The tree diameter at breast height (dbh) of orangutan nest in the Prevab was a range of $20 \mathrm{~cm}$ to $126 \mathrm{~cm}$ with an average of $56 \mathrm{~cm}$. Orangutans in this location commonly built about $92.31 \%$ of their nests on big trees $(\mathrm{dbh}>30 \mathrm{~cm})$. For CMRA, the $\mathrm{dbh}$ of nest trees was a range of $5 \mathrm{~cm}$ to $50 \mathrm{~cm}$ with an average of $15 \mathrm{~cm}$. Most of the orangutans establish their nests on small-diameter trees $(d b h \leq 20 \mathrm{~cm})$. The highest frequency of use in the CMRA is classified as $d b h$ in a range of $10.1 \mathrm{~cm}$ to $15 \mathrm{~cm}(46.67 \%)$. Other tree classes are in a dbh range of $5.1 \mathrm{~cm}$ to $10 \mathrm{~cm}(26.67 \%)$, and $15.1 \mathrm{~cm}-20 \mathrm{~cm}(10 \%)$.

The analysis result of Man Whitney regarding the tree dbh differences of orangutan nests indicates a significant difference between these two habitats ( $N: 147 ; P 0.000<0.005)$. The nest tree $d b h$ distribution of both habitat types is characterized in Figure 6.

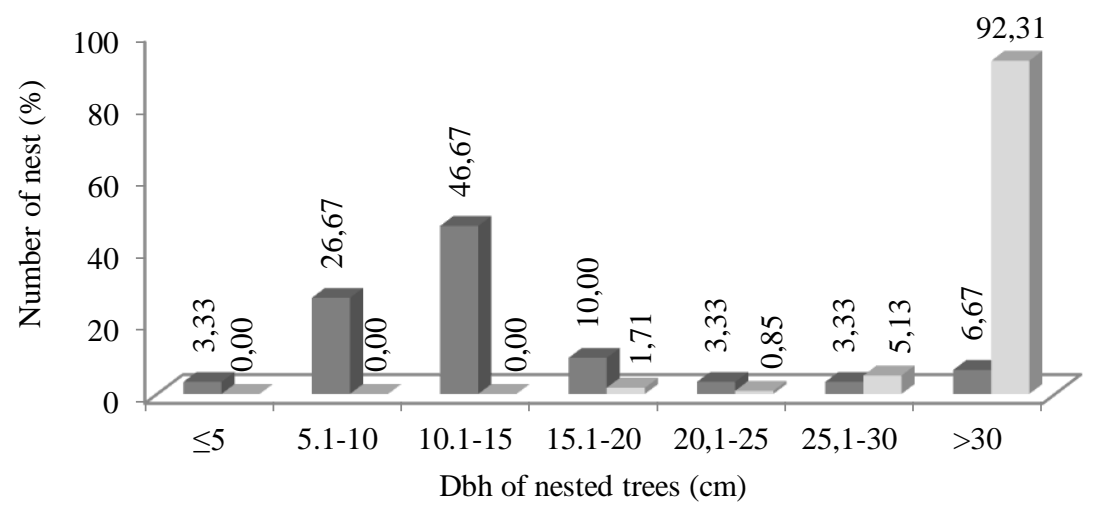

Figure 6. Percentages of dbh (cm) distribution of orangutan nested trees at CMRA ( $\square$ ) and Prevab(

The height of trees used as nest trees by orangutans in CMRA around 5 to $30 \mathrm{~m}$ with the highest frequency at the class of height of 10.1-15 m. In Prevab, the height of the nest tree ranges from 10-40 $\mathrm{m}$ with the highest frequency was at the height class of 20.1-25 $\mathrm{m}$ (Figure 7).



Height of nest trees (m)

Figure 7. Percentages of height $(m)$ distribution of orangutan nest trees at CMRA ( $\square$ ) and Prevab( $\square)$

[103] This work is licensed under a Creative Commons Attribution 4.0 International License 


\section{Characteristics of nests}

Orangutans at CMRA frequently built their nests distinguishing in five classes of high ranges from ground level namely $10.1 m-15 m$ (37.84\%), $5.1 m-10 m$ (29.73\%), 15.1-20 $m$ (25.68\%), 25.1-30 m (5.41\%), and 20.1-25 (1.35\%). At Prevab, orangutans often set their nests categorizing in five classes of high ranges from ground level namely 20.1-25 m (36.59\%), 15.1-20 m (32.52\%), $25.1 .30 \mathrm{~m}$ (14.63\%), >30 $\mathrm{m}$ (8.13\%), and 10.1-15 $\mathrm{m}$ (8.13\%).

Most of the nests built by orangutans in both habitats were new nests with a lower percentage at CMRA than at Prevab (64.47\% vs (83.61\%). Orangutans at CMRA frequently repair their old nests (reused nests) as a resting place at night than the orangutans at Prevab (35.53\% vs 15.57\%) (Figure 8). They fixed up the old nests by adding more new branches/limbs to the old nest structures.



Figure 8. Number of new nests and reused nestsat CMRA $(n=74)$ and Prevab $(n=123)$

The flanged males (FM) in the CMRA utilized the reused nests in the highest proportion, followed by adolescence (Adol), unflanged males (UFM), dan adult females $(A F)$. Furthermore, the repaired nests in the Prevab are occupied by FM at the highest level, then followed by Adol and AF (See Table 1).

Table 1. Percentage of nest numbers according to nest types and sex-age classes (focal) at CMRA and Prevab

\begin{tabular}{lrrrr}
\hline \multirow{2}{*}{ Focal } & \multicolumn{2}{c}{ New nest } & \multicolumn{2}{c}{ Reused/repaired nest } \\
\cline { 2 - 5 } & CMRA & Prevab & CMRA & Prevab \\
\hline FM & 33.33 & 71.43 & 66.67 & 28.57 \\
UFM & 66.67 & 100.00 & 33.33 & 0.00 \\
AF & 68.33 & 85.71 & 31.67 & 14.29 \\
Adol & 50.00 & 60.00 & 50.00 & 40.00 \\
All & 64.47 & 83.61 & 35.53 & 16.39 \\
\hline
\end{tabular}

Orangutans at CMRA choose more often building their nests on a position of 3/ shoots of trees than other positions. This is manifested by a high frequency of nesting at this position (63.51\%), then followed by a position of 2/edge of branches (27.03\%), a position of $4 /$ two trees or more (5.41\%), and a position of $1 /$ main branches $(4.05 \%)$. At Prevab, the orangutans set more often their nests on a position 2 (51.67\%), position 3 (36.67\%), and position 1 (11.67\%). The frequency of choosing nest position for orangutans in both research locations is presented in Figure 9.

The results of observation at CMRA exhibit that the numbers of opened nests reach $82.67 \%$ and closed one is only $17.33 \%$ of total built nests of orangutans. Data regarding 
nest protecting by tree canopy in the Prevab area of Kutai National Park is not available, as a comparison, we used the research results of Niningsih (2009).



Figure 9. Frequency of selected of nest-sites location on trees by orangutans at CMRA $(\mathrm{N}=74)$ and Prevab $(\mathrm{N}=120)$.

\section{Discussion}

\section{Characteristics of nest trees}

At Prevab, ulin was the most frequently used as a nest tree, even though, this species was not a dominant tree in the Prevab. This finding is similar to the research results conducting by Niningsih (2009) in Prevab and Ancrenaz et al. (2004) in Kinabatangan, showing, though, many species used by orangutans as nest tree, however, ulin was the favorite nest tree.

At CMRA, orangutans live on existing tree species as their nesting places. Anyhow, there are some species seemingly is more preferable and some others are not favorable even though available in enough number. Sengon (Falcataria moluccana) and johar (Senna surattensis) are dominant trees enough at CMRA (Niningsihet al. 2017), but the frequency of using these tree species as nests were low. In vice versa, gmelina (Gmelina arborea), although, in a relatively small number and is not evenly distributed in the CMRA, however, its frequency of use as a nest tree by the orangutans is higher than sengon and johar. The gmelina, at the same tree, has been observed that this tree is utilized by one of the orangutans (Clara) as many as three times and two of them are the reused nest in seven days of observation. Almost every gmelina trees at CMRA is occupied by at least more than two orangutan nests. This tree species is strongly thought to be a favorable nest tree of orangutans in the CMRA (Figure 10).

The botanical plot analysis in the CMRA showed that this area is measly discovered largediameter trees (Niningsih et al. 2017). This condition explains why the orangutans in this area more frequently making their nests on small-diameter trees $(d b h \leq 20 \mathrm{~cm})$.

The botanical plot analysis in the Prevab denoted that the number of trees decreases with increasing tree diameter size (Niningsih et al. 2016). That is one of the climax natural forest structure characteristics in Borneo (Meyer 1952). Trees with a smaller diameter $(\mathrm{dbh} \leq 30 \mathrm{~cm})$ are found in a more amount than the larger diameter in the Prevab of Kutai National Park, but the most frequently used by orangutans as their nest places are trees with a diameter of $\geq 30$ $\mathrm{cm}$. The research results of Ancrenaz et al. (2004) in Kinabatangan, Sabah in Malaysia at a degrading habitat regarding the percentage of $d b h(\mathrm{~cm})$ distribution of nest trees and trees in their research location indicate a similar pattern. 


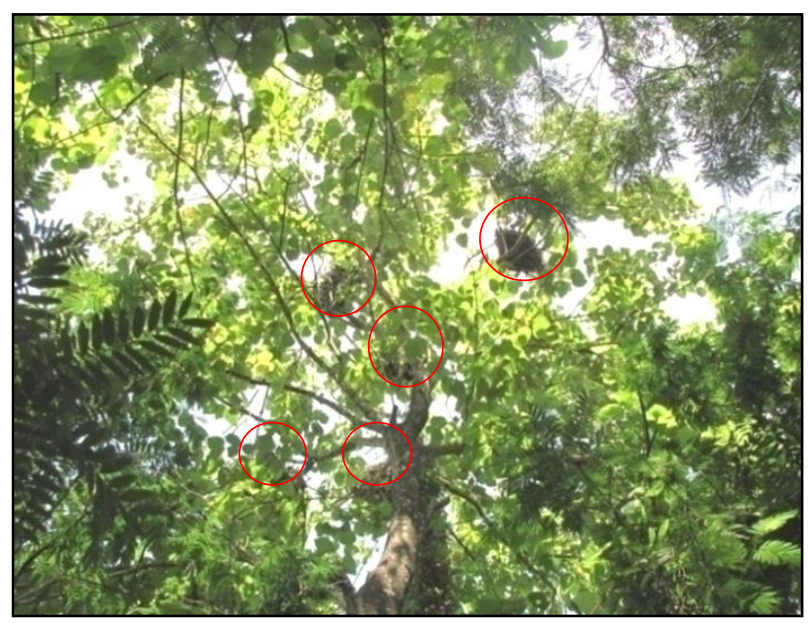

Figure 10. We observed a gmelina tree harbored 5 nests at CMRA.

The height of nest trees of orangutans in the CMRA fluctuated following the height distribution of existing trees, however, there was a tendency of the orangutans choosing high trees if they are available (Figure 11).



Figure 11. Percentages of distribution of height $(m)$ of nest trees and trees in the botanical plot at CMRA

The description above explains the distributions of $d b h$ and nest tree height fluctuate by the distributions of available $d b h$ and tree height in the forest. Orangutans can adapt employing small trees in the CMRA as their nests, however, they tend to choose larger trees for establishing their nests if in their habitat the larger trees are available in enough numbers.

\section{Characteristics of Nests}

The findings at CMRA indicate that the nest height average of orangutans from the ground level is lower than the Prevab one. Orangutans in this location frequently build their nests on a height of $<20 \mathrm{~m}$, even their nesting frequency on the height of $<10 \mathrm{~m}$ is high enough ( $\pm 30 \%)$. In a natural habitat, majority of orangutans are discovered on a height range of 10 and $30 \mathrm{~m}$ in a tree middle layer and their nests are measly built on high young trees, for instance, the research conducted by MacKinnon (1974) in Ulu Segama, 
Ancrenaz (2006) in Kinabatangan Sabah, and Sugardjito (1983) in Ketambe. The upper canopy layer locating above the nests is perceived as contributing to extra protection to the orangutans during sleeping from direct sunlight and/or raining (Ancrenaz et al. 2004). Figure 12 presents a percentage comparison of orangutans' nest height at CMRA with nest heights in some natural habitats.

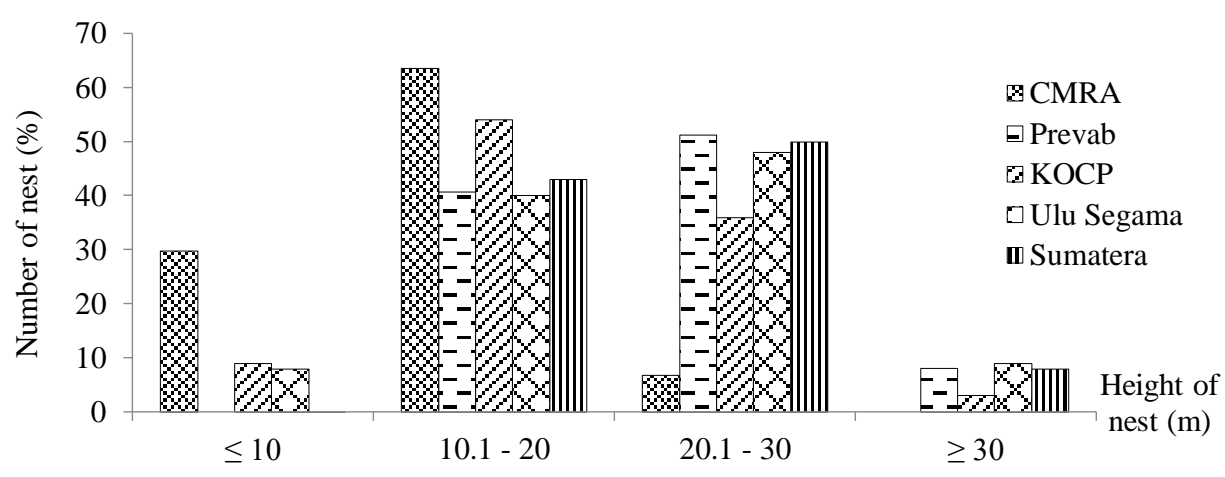

Figure 12. Percentages of height distribution of nests at CMRA (this study), Kinabatangan/KOCP (Ancrenaz et al. 2004), Ulu Segama (MacKinnon 1974) and Sumatera (Sugardjito1983).

Orangutansat CMRA set their nests on a lower height namely on the height of $<20 \mathrm{~m}$ following of the available high trees distribution in this area. This hypothesis is proven by a positive correlation between the nest height of orangutans and nest tree height ( $N=60 ; P=$ 0.00) (Figure 13).

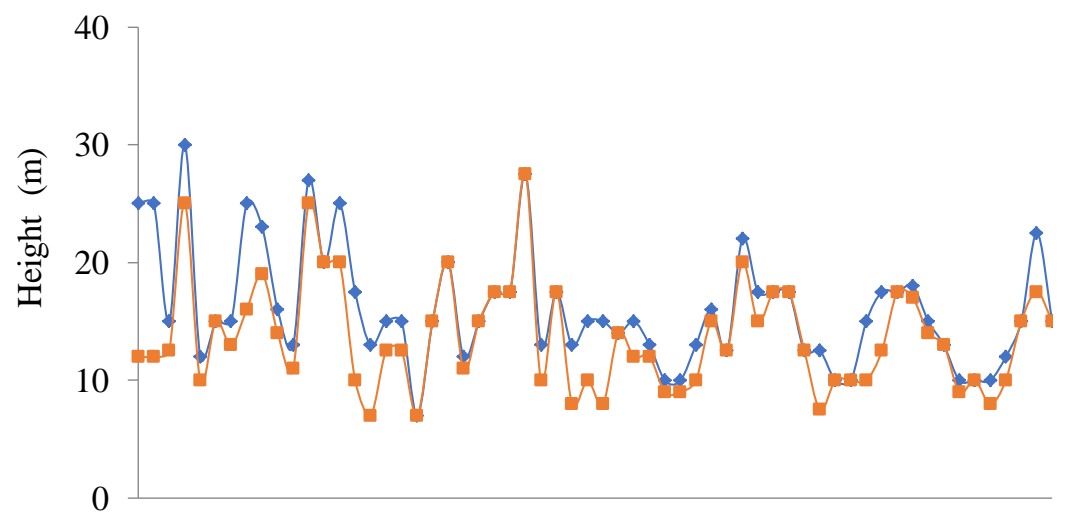

Figure 13. Distribution of nests height (--) and height of orangutan nest trees (-^-) at CMRA

At CMRA, a large number enough of nests are found with a height of $<5 \mathrm{~m}$, however, they do not belong to the observed orangutans. During the field observation, the nests were found on the ground level also, but they are not recognized as the night or day nests. This condition exhibits that during no observers, orangutans in the CMRA sometimes build their nests on smaller trees than the even observed directly (Figure 14). 




Figure 14. Orangutan nest at the height of $\pm 1.5 \mathrm{~m}$ at $\mathrm{CMRA}$

The number proportion, of opened nests in the CMRA, reaches $82.67 \%$, is higher than the Prevab which is only 39.7\% (current research) and in Bhirawa exceeding 50.0\% (Niningsih 2009). This percentage difference is due to the different habitat of both research locations(Figure 15). Prevab is a habitat with good conditions where the vertical and horizontal forest structures are still complete (Niningsihet al. 2017), therefore, some nests locating at limb edges and treetops are still protected by other trees from both the side and above. Reversely, the habitat in the CMRA is dominated by young trees with tend evenly dimension(Niningsihet al. 2017), accordingly, there is not any canopy protection for the nests situating on the treetops and branch edges.

The wild orangutans build their night nests every afternoon or dusk as their resting places in the night. In common, orangutans build their new nests, but occasionally they also repair their old nests as sleeping locations. The research results in some different locations point out that a proportion of using the reused nests by orangutans is higher in the disturbed habitat. A research conducted by Rayadin and Saitoh (2009) also implies a similar result namely about $31.9 \%$ of discovered nests in the conservational forest of Forest Plantation of PT Surya Hutan Jaya site at Bhirawais the reused nest. This number is higher than orangutans in Meratus (28.0\%), and Prevab (25.0\%).

The wild orangutans at CMRA utilize the reused nest in a higher proportional than other various research sites. A limitation of nest tree number with the stable buffering branches for building nest structures is surmised becoming a cause of high proportional utilized the reused nests by orangutans of CMRA.

The highest tree proportion of use for the reused nests is Gmelina arborea (55.89\%). This is supposedly due to this tree possesses a more suitable canopy profile and ramification functioning as places to set nests than other tree species at CMRA.

FM at CMRA and Prevab utilized the reused nests higher than the other focal classes with a very high proportion in CMRA (66.67\%). Ancrenaz et al. (2004) found a similar pattern on orangutans in Kinabatangan (22.4\% for UFM; $17.9 \%$ for FM; and only $13.7 \%$ for female). Rayadin and Saitoh (2009) also discover a higher proportion of reused nests for FM (43.3\% from 30 times of nest events) in East Kalimantan. The male orangutans, have larger bodies and heavier, need stronger branches than the female. This causes the appropriate trees as their nesting places to be getting limited. Hence, the adult males especially FM may become more frequently utilize the reused nests. They might not have many options in selecting trees as their nesting places due to the 
limitedness of available larger trees numbers at CMRA. Furthermore, reused old nests also can save time and energy than establish a new one.

The frequency of use tree top position as a nest at CMRA was higher than the natural habitat. Selecting this position is surmised due to the small-diameter trees with small ramification is the most dominant at CMRA (Niningsih et al. 2017).

Orangutans tend to choose strong tree parts as supporting their nest structures, commonly a large branch or a group of stable branches, branching branches, or stable gap (van Casteren et al. 2012). Also, the surrounding weaker and flexible branches are used to accomplish the nest construction (forming a base and mattress) and often are completed by leaves and herbs.

Locations of nests on trees are surmised relating to the profile of trees situating in the forest. Selecting the middle and axilla branches in the natural habitat by the orangutans is expected due to those parts are available strong supports for the construction of nests that can hold weights of orangutans, especially on trees with narrow canopy profiles like the young to middle age of ulin. On larger trees with wider canopy and big branching as well as maybe the branch edges are suitable and strong enough as a support of the nest construction. In addition, the middle and axilla position of branches also contribute to protecting the orangutans from rain and sun exposures if the nest is not protected by other higher tree canopy layers.

Last, orangutans at CMRA adapted to build nests on varied species and dimensions of trees. They established more frequently nests on the treetops, and the proportion of reused nests was higher than orangutans in the natural habitats.

\section{CONCLUSION}

In conclusion, habitat changes in CMRA have encouraged orangutans living in the area to adapt one of which is in terms of nesting behavior. Orangutans at CMRA adapted to build nests on varied species and dimensions of trees, including small trees. The proportion of reused nests by orangutan at CMRA was higher than orangutans in the natural habitat and they established more frequently nests on the tree tops.

\section{ACKNOWLEDGEMENTS}

We are very grateful to PT KPC at Sangatta and The Kutai National Park (KNP) for granting us permission to conduct research in their areas. We thank the College of Agricultural (STIPER) Kutai Timur, IPB University, and provincial government East Kalimantan. We are also indebted to the personals and organizations who provided logistical and organizational support in the field: STIPER Kutai Timur (Arbain, I. M. Ramadhan), field assistants at KNP (S. Nur Bani, Darim, Nala, Udin, Junudi), and field assistants at PT KPC (D. Nugraha, T.C. Manulang, Saiful, Sugeng, Munir, Constant, Y. Musa, Fauzan, Kurnia, etc). The research complied with Indonesian legal requirements and was approved by the relevant institutional committees of the nation of Indonesia.

\section{REFERENCES}

Ancrenaz M, Calaque R, Lackman-Ancrenaz I. 2004. Orangutan nesting behavior in disturbed forest of Sabah, Malaysia: implications for nest census. International Journal of Primatology 25(5): 983-1000.

[109] This work is licensed under a Creative Commons Attribution 4.0 International License 
Ancrenaz M, Oram F, Ambu L, Lackman I, Ahmad E, Elahan H, Kler H, Abram NK, Meijaard E. 2014. Of Pongo, palms and perceptions: a multidisciplinary assessment of Bornean orangutans Pongo pygmaeus in an oil palm context. Oryx 42: 1-8.

Ancrenaz M. 2006. Final Report: Consultancy on Survey Design and Data Analysis at Betung Kerihun National Park, Indonesia. WWF Indonesia Betung Kerihun Project, Betung Kerihun.

Anderson JR. 2000. Sleep-related behavioural adaptations in freeranging anthropoid primates. Sleep Medicine Reviews 4(4): 355-373.

Baldwin PJ, Sabater Pi J, McGrew WC, Tutin CEG. 1981. Comparisons of nests made by different populations of chimpanzees (Pan troglodytes). Primates 22(4): 474-486.

Brownlow AR, Plumptre AJ, Reynolds V, Ward R. 2001. Sources of variation in the nesting behavior of chimpanzees (Pan troglodytes schweinfurthii) in the Budongo Forest, Uganda. International Journal of Primatology 55(1): 49-55.

Campbell NA, Reece JB, Urry LA, Cain ML, Wasserman SA, Minorsky PV, Jackson RB. 2008. Biology Eighth edition. In: Hardani W, Adhika $P$ (eds) Biologi Edisi Kedelapan Jilid 3. Penerbit Erlangga, Jakarta.

Campbell-Smith G, Campbell-Smith M, Singleton I, Linkie M. 2011. Raiders of the lost bark: Orangutan foraging strategies in a degraded landscape. PloS ONE 6(6): e20962.

Candolin U, Wong BBM. 2012. Behavioural Responses to a Changing World: Mechanisms and Consequences. Oxford University Press, Oxford.

Curtis JT. 1959. The Vegetation of Wisconsin: An Ordination of Plant Communities. Wisconsin University Pr., Madison.

Fruth B, Hohmann G. 1994. Comparative analysis of nest building behaviour in bonobos and chimpanzees. In: Wrangham RW, McGrew WC, de Waal FBM, Heltne PG (eds) Chimpanzee Cultures. Harvard University, London.

Gunawan H, Prasetyo LB. 2003. Fragmentasi Hutan: Teori yang Mendasari Penataan Ruang Menuju Pembangunan Berkelanjutan. Balitbang Kehutanan Kemenhut, Jakarta.

Hall JS, White LJT, Inogwabini BI, Omari I, Simons Morland H, Williamson EA, Saltonstall K, Walsh P, Sikubwabo C, Bonny $D$ et al. 1998. Survey of Grauer's gorillas (Gorilla gorilla graueri) and eastern chimpanzees (Pan troglodytes schweinfurthi) in the Kahuzi-Biega National Park lowland sector and adjacent forest in Eastern Democratic Republic of Congo. International Journal of Primatology 19: 207-235.

Hardus ME, Lameira AR, Menken-Steph BJ, Wich SA. 2012. Effects of logging on orangutan behavior. Biological Conservation 146(1): 177-187.

Humle T. 2003. Culture and Variation in Wild Chimpanzee Behaviour: A Study of Three Communities in West Africa [Dissertation]. University of Stirling, Stirling [Scotland].

Husson SJ, Wich SA, Marshall AJ, Dennis RD, Ancrenaz M, Brassey R, Gumal M, Hearn AJ, Meijaard E, Simorangkir T, Singleton I. 2009. Orangutan distribution, density, abundance and impacts of distrurbance. In Wich SA, Utami Atmoko SS, Mitra Setia T, van Schaik CP (eds) Orangutans: Geographic Variation in Behavioral Ecology and Conservation. Oxford Univ Pr., New York.

Koops K, McGrew WC, Matsuzawa T, Knapp LA. 2012. Terrestrial nest-building by wild chimpanzees (Pan troglodytes): implications for the tree-to-ground sleep transition in early hominins. American Journal of Physical Anthropology 148(3): 351-361.

KPC. 2013. Burning On: 2013 Sustainability Report. PT Kaltim Prima Coal, Sangatta Kutai Timur.

Lynch M, Gabriel W. 1987. Environmental Tolerance. The American Naturalist 129(2): 283-303.

MacKinnon J. 1974. The behavior and ecology of wild orangutan (Pongo pymaeus). Animal Behaviour 22(1): 3-74.

McGrew WC. 2004. The Cultured Chimpanzee: Reflections on Cultural Primatology. Cambridge University Press, Cambridge. 
Meijaard E, Rijksen HD, Kartikasari SN. 2001. Di Ambang Kepunahan, Kondisi Orangutan Liar di Awal Abad 21. The Gibbon Foundation, Jakarta.

Meyer HA. 1952. Structure, growth, and drain in balanced uneven-aged forests. Journal of Forestry 50(2): 85-92.

Morrogh-Bernard HC, Husson SJ, Knott CD, Wich SA, van Schaik CP, van Noordwijk MA, Lackman-Ancrenaz I, Marshall AJ, Kanamori T, Kuze N, Sakong R. 2009. Orangutan activity budgets and diet: A Comparison between species, populations and habitats. In: Wich SA, Utami Atmoko SS, Mitra Setia T, van Schaik CP (eds) Orangutans: Geographic Variation in Behavioral Ecology and Conservation. Oxford Univ Pr., New York.

Ngatiman. 2001. Studi Tentang kerusakan tegakan Acacia Mangium Willd dan kehadiran orangutan (Pongo pygmaeus pygmaeus) di PT Surya Hutani Jaya [Thesis]. Mulawarman University, Samarinda. [Indonesian]

Niningsih L, Alikodra HS, Utami-Atmoko SS, Mulyani A. 2016. Habitat Characteristic of Pongo pygmaeus morio in Prevab Area, Kutai National Park, Borneo, Indonesia. International Journal of Sciences: Basic and Applied Research (IJSBAR) 30(3): 8-20.

Niningsih L, Alikodra HS, Utami-Atmoko SS, Mulyani A. 2017. Characteristic of Orangutan Habitat in Coal Mining Rehabilition Area in East Kalimantan, Indonesia. Jurnal Manajemen Hutan Tropika 23(1): 37-49.

Niningsih L. 2009. The Studies on characteristic interrelationship between nest and its rate of decay, and the implication to an estimation of orangutan's density [Thesis]. Mulawarman University, Samarinda. [Indonesian]

Niningsih L. 2017. A Behavioral Adaptation of Orangutan (Pongo pygmaeus morio) in the Area of Coal Mining in East Kalimantan [Dissertation]. IPB University, Bogor. [Indonesian]

Ogawa H, Idani G, Moore J, Pintea L, Hernandez-Aguilar A. 2007. Sleeping parties and nest distribution of chimpanzees in the savanna woodland, Ugalla, Tanzania. International Journal of Primatology 28(6): 1397-1412.

pada:http://www.aim.uzh.ch/dam/jcr:00000000-31fd-16f1-ffff-fff64ca75e/.

Poulsen JR, Clark CJ. 2004. Densities, distributions and seasonal movements of gorillas and chimpanzees in swamp forest in Northern Congo. International Journal of Primatology 25(2): 285-306.

Prasetyo D, Ancrenaz M, Morrogh-Bernard HC, Utami Atmoko SS, Wich SA, Van Schaik CP. 2009. Nest building in orangutans. In: Wich SA, Utami Atmoko SS, Mitra Setia T, van Schaik CP (eds) Orangutans: Geographic Variation in Behavioral Ecology and Conservation. Oxford Univ Pr., New York.

Pruetz JD, Fulton SJ, Marchant LF, McGrew WC, Schiel M, Waller M. 2008. Arboreal nesting as anti-predator adaptation by savanna chimpanzees (Pan troglodytes verus) in southeastern Senegal. American Journal of Primatology 70(4): 393-401.

Rai MK, Carpinella C. 2006. Naturally Occurring Bioactive Compounds. Elsevier, Amsterdam.

Rayadin Y, Boer C, Masrun H, Rochmadi S, Sutrisman A, Hanggito MS, Syamsudin J. 2012. Laporan Analisis Distribusi Populasi dan Perilaku Orangutan pada Kawasan Reklamasi Pasca Tambang PT Kaltim Prima Coal. Ecositrop-PPHT-UNMUL, Samarinda.

Rayadin Y, Saitoh T. 2009. Individual Variation in Nest Size and Nest Site Features of the Bornean Orangutans (Pongo pygmaeus). International Journal of Primatology 71(5): 393399.

Rayadin Y, Spehar NS. 2015. Brief communication: body mass of wild bornean orangutans living in human-dominated landscapes: implications for understanding their ecology and conservation. American Journal of Physical Anthropology 157(2): 339-346.

Reader SM, MacDonald K. 2003. Environmental variability and primate behavioral flexibility. In: Reader SM, Laland KN (eds) Animal innovation. Oxford Univ Pr., New York.

Sanz C, Morgan D, Strindberg SC. 2007. Distinguishing between the nests of sympatric chimpanzees and gorillas. Journal of Applied Ecology 44(2): 263-272.

[111] This work is licensed under a Creative Commons Attribution 4.0 International License 
Sih A, Ferrari MCO, Harris DJ. 2011. Evolution and behavioural responses to human-induced rapid environmental change. Evolutionary Applications 4(2): 367-387.

$\operatorname{Sih}$ A. 2013. Understanding variation in behavioural responses to humaninduced rapid environmental change: a conceptual overview. Animal Behaviour 85(5): 1077-1088.

Sol D, Timmermans S, Lefebvre L. 2002. Behavioural flexibility and invasion success in birds. Animal Behaviour 63(3): 495-502.

Sol D. 2003. Behavioural innovation: a neglected issue in the ecological and evolutionary literature?. In: Reader SM, Laland KN (eds) Animal innovation. Oxford Univ Pr., New York.

Stewart FA, Pruetz JD, Hansell MH. 2007. Do chimpanzees build comfortable nests? International Journal of Primatology 69(8): 930-939.

Stewart FA, Pruetz JD. 2013. Do chimpanzee nests serve an anti-predatory function?. International Journal of Primatology 75(6): 593-604.

Sugardjito J. 1983. Selecting Nest-sites of Sumatran Orang-utans, Pongo pygmaeus abelii in the Gunung Leuser National Park, Indonesia. Primates 24(4): 464-474.

Sugiyono. 2007. Statistika untuk Penelitian. Penerbit Alfabeta, Bandung.

Tutin CEG, Fernandez M. 1984. Nationwide census of gorilla (Gorilla g. gorilla) and chimpanzee (Pan t.troglodytes) populations in Gabon. International Journal of Primatology 6(4):313-336.

van Casteren A, Sellers WI, Thorpe SKS, Coward S, Crompton RH, Myatt JP, Ennos AR. 2012. Nest-building orangutans demonstrate engineering know-how to produce safe, comfortable beds. Biological Sciences-Anthropology 109(18): 6873-6877.

van Schaik CP, Wich SA, Utami-Atmoko SS, Odom K. 2005. A simple alternative to line transects of nests for estimating orangutan densities. Primates 46(4):249-254.

van Schaik CP. 1983. Why are diurnal primates living in groups?. Behaviour 87(1/2):120-144.

van Schaik CP. 2006. Why are some animals so smart?. Scientific Amarican 16(1): 30-37.

Wich SA, Streubig M, Refisch J, Wilting A, Kramer-Schadt S, Meijaard E. 2015. Summary Report: The Future of The Bornean Orang-utan, Impacts of Change in Land-Cover and Climate. www.unep.org. 